\title{
PENGARUH KEPUTUSAN INVESTASI, KEPUTUSAN PENDANAAN, KEBIJAKAN DIVIDEN DAN UKURAN PERUSAHAAN TERHADAP NILAI PERUSAHAAN
}

\author{
Hesti Setyorini Pamungkas \\ Alumni Program Studi AkuntansiUniversitas Islam Indonesia \\ e-mail: hesti.pamungkas@yahoo.com \\ Abriyani Puspaningsih \\ Universitas Islam Indonesia Yogyakarta \\ e-mail: abriyani@uii.ac.id
}

\begin{abstract}
This study aims to examine the effect of investment decisions, financing decisions, dividend policy and firm size on the firm value. Firm value on this research measured by Price to Book Value $(P B V)$. The study used purposive sampling method for determining the number of sample. Samples in this study were 25 manufacturing companies listed on the Indonesia Stock Exchange, which has published a financial report from 2009-2011. Methods of analysis in this study using multiple regression analysis. The results show that investment decisions positively affects the firm value. However, financing decisions, dividend policy and firm size did not affect the firm value.
\end{abstract}

Keywords:Investment decision, financingdecisions, dividend policy, firmsize,firm value

\begin{abstract}
Abstrak
Artikel ini bertujuan menguji hubungan antara keputusan investasi, keputusan pendanaan, kebijakan deviden dan ukuran perusahaan terhadap nilai perusahaan. Dalam penelitian ini, nilai perusahaan diukur dengan Price to Book Value (PBV). Studi ini menggunakan purposive sampling method untuk menentukan jumlah sampel. Sampel yang digunakan dalam penelitian ini berjumlah 25 perusahaan manufaktur yang terdapat di Bursa Efek Indonesia yang menerbitkan laporan keuangan untuk periode 2009-2011. Metoda analisis data menggunakan regresi berganda. Hasil penelitian menunjukkan bahwa keputusan investasi berpengaruh positif terhadap nilai perusahaan. Meskipun demikian, keputusan pendanaan, kebijakan deviden dan ukuran perusahaan tidak berpengaruh terhadap nilai perusahaan.
\end{abstract}

Kata kunci: keputusan investasi, keputusan pendanaan, kebijakan deviden, ukuran perusahaan, nilai perusahaan

\section{PENDAHULUAN}

Perusahaan pada umumnya bertujuanuntuk memaksimalkan laba atau profit.Ketika sebuah perusahaan memperoleh laba yang besar, maka hal itu dapat menaikkan nilai perusahaan. Jika nilai perusahaan meningkat akan membuat harga pasar perusahaanmeningkat pula.

Manajer keuangan dapat melakukan beberapa pengambilan keputusan agartujuan perusahaan dapat tercapai. Ketepatan pengambilan keputusan sangat tergantung pada keakuratan data akuntansi yang tersedia.
Dengan demikian peran akuntan sangatlah besar dalam menentukan ketepatan pengambilan keputusan.

Untuk mencapai tujuan perusahaan beberapa pengambilan keputusan yang diambil antara lain adalah keputusan investasi, keputusan pendanaan dan kebijakan dividen. Keputusan investasi akan mempengaruhi struktur kekayaan perusahaan, yaitu perbandingan antara aktiva lancar dengan aktiva tetap. Menurut signaling theory, pengeluaran investasi memberikan sinyal positif mengenai 
pertumbuhan perusahaan di masa yang akan datang, sehingga dapat meningkatkan harga saham yang digunakan sebagai indikator nilai perusahaan(Wahyudi dan Pawestri2006).

Keputusan selanjutnya yang harus dibuat oleh manajer keuangan yaitu apakah dana yang akan digunakan oleh perusahaan berasal dari sumber internal perusahaan atau sumber eksternal. Selain itu juga menentukan besarnya hutang dan modal sendiri serta menentukan bagaimana tipe hutang dan modal yang akan digunakan. Hal ini mengingat struktur pembiayaan akan menentukan cost of capital yang akan menjadi dasar penentuan required return yang diinginkan(Hasnawati 2005).

Pada saat perusahaan telah dapat beroperasi dengan lancar dan memperoleh laba,maka keputusan berikutnya yang diambil perusahaanadalah apakah perusahaan akan membagikan dividen atau menahan laba. Keputusan ini disebut dengan kebijakan dividen. Manajer keuangan dapat memutuskan kebijakan dividen terbaik dan juga memutuskan waktu kapan mereka akan membagikan dividen dan kapan akan menahan laba, dengan keputusan yang tepat maka akan menaikkan nilai perusahaan.

Selain faktor-faktor di atas, dalam penelitian ini penulis menambahkan ukuran perusahaan sebagai faktor lain yang mempengaruhi nilai perusahaan. Dalam penelitian ini ukuran perusahaan diukur dari total aktiva yang dimiliki oleh perusahaan. Menurut Sujoko (2007) ukuran perusahaan yang besar menunjukkan perusahaan mengalami perkembangan,sehingga investor akan merespon positif dan nilai perusahaan akan meningkat.Penelitian ini bertujuan untuk mengetahui pengaruh keputusan investasi, keputusan pendanaan, kebijakan dividen dan ukuran perusahaan terhadap nilai perusahaan.

\section{TINJAUAN PUSTAKA DAN PERUMUSAN HIPOTESIS}

Keputusan Investasi, Keputusan Pendanaan dan Kebijakan Dividen

Banyak upaya yang harus dilakukan oleh manajer keuangan untuk dapat mencapai tujuan manajemen keuangan sehingga meningkatkan nilai perusahaan. Keputusankeputusan yang harus dilakukan oleh manajer keuangan yaitu, keputusan investasi, keputusan pendanaan dan kebijakan dividen. Keputusan-keputusan yang dibuat oleh manajer keuangan secara tepat akan menaikkan harga saham perusahaan sehingga diikuti dengan kenaikan nilai perusahaan secara langsung maupun tidak langsung.

Keputusan investasi akan mempengaruhi struktur kekayaan perusahaan, yaitu perbandingan antara aktiva lancar dengan aktiva tetap. Menurut Martono dan Harjito (2010), investasi merupakan penanaman dana yang dilakukan oleh suatu perusahaan ke dalam suatu aset (aktiva) dengan harapan memperoleh pendapatan dimasa yang akan datang. Dari pengertian tersebut dapat disimpulkan bahwakeputusan investasi dimulai dengan penetapan jumlah total aktiva yang perlu dimiliki oleh perusahaan dengan penetapan jumlah aktiva yang tepat, akan membuat investasi yang dilakukan akan berhasil baik, sehingga dapat meningkatkan nilai perusahaan.

Keputusan investasi memiliki salah satu aspek utama yaitu investasi modal. Keputusan pengalokasian modal ke dalam usulan investasi harus dievaluasi dan dihubungkan dengan risiko dan hasil yang diharapkan(Hasnawati 2005). Menurut signaling theory, pengeluaran investasi memberikan sinyal positif mengenai pertumbuhan perusahaan di masa yang akan datang, sehingga dapat meningkatkan harga saham yang digunakan sebagai indikator nilai perusahaan. (Wahyudi danPawestri2006). Sedangkan menurut pendapat Uri Ben-Zion (1984) nilai pasar perusahaan dipengaruhi oleh research and development dan kebijakan investasi.

Keputusan selanjutnya yang harus dibuat oleh manajer keuangan yaitu mengenai keputusan tentang bentuk dan komposisi pendanaan yang akan dipergunakan oleh perusahaan atau dapat kita sebut keputusan pendanaan. Manajer keuangan harus memutuskan apakah dana yang akan perusahaan gunakan berasal dari sumber internal perusahaan atau sumber eksternal, besarnya hutang dan modal sendiri, dan bagaimana tipe hutang dan modal yang akan digunakan, mengingat struktur pembiayaan akan menentukan cost of capital yang akan menjadi dasar penentuan required 
return yang diinginkan(Hasnawati2005). Dengan demikian manajer keuangan harus dapat membuat keputusan tentang bentuk dan komposisi dana yang terbaik yang akan digunakan oleh perusahaan untuk dapat mengoptimalkan nilai perusahaan.

Ketika kegiatan operasional perusahaan telah berjalan dengan lancar dan pendapatan yang diperoleh juga stabil serta perusahaan sudah dapat memperoleh laba,maka keputusan selanjutnya adalah keputusan mengenai kebijakan dividen. Perusahaan harus memutuskan laba yang diperoleh akan dibagikan sebagai dividen atau menahan laba. Manajer keuangan harus memikirkan dengan tepat jika perusahaan membagikan dividen kepada para pemegang saham agarpada tahun berikutnya kegiatan operasional tetap dapat berjalan dengan baik. Sebaliknya jika manajer keuangan memutuskan untuk menahan laba perusahaan, maka laba tersebut dapat digunakan untuk melakukan ekspansi perusahaan. Dengan dilakukannya ekspansi makalaba perusahaan akanmenjadi lebih besar, sehingga diharapkan dapat menambah kesejahteraan bukan hanya untuk pihak yang mengelola perusahaan tapi juga para pemegang saham. Manajer keuangan dapat memutuskan kebijakan dividen terbaik yang akan mereka ambil dan juga memutuskan kapan waktu pembagian dividen dan kapan akan menahan laba, dengan keputusan tepat akan menaikkan nilai perusahaan.

Aspek penting dari kebijakan dividen adalah menentukan alokasi laba yang sesuai di antara pembayaran laba sebagai dividen dengan laba yang ditahan di perusahaan. Perusahaan yang mempunyai ukuran besar memiliki fleksibilitas dan aksesbilitas untuk memperoleh dana dari pasar modal. Kemudahan tersebut ditangkap investor sebagai sinyal positif dan prospek yang baik sehingga dapat memberikan pengaruh positif terhadap nilai perusahaan.

Beberapa penelitian tentang pengaruh keputusan investasi, keputusan pendanaan dan kebijakan dividen terhadap nilai perusahaan telah dilakukan. Hasnawati (2005) menggunakan beberapa indikator keputusan keuangan yang mempengaruhi nilai perusahaaan. Berdasarkan hasil penelitian tersebut ditarik kesimpulan bahwa keputusan investasi, keputusan pendanaan dan kebijakan dividen berpengaruh terhadap nilai perusahaan.

Wijaya dan Wibawa (2010) meneliti mengenai faktor keputusan keuangan yang mempengaruhi nilai perusahaan. Berdasarkan hasil penelitian tersebut ditarik kesimpulan bahwa keputusan investasi, keputusan pendanaan dan kebijakan dividen berpengaruh terhadap nilai perusahaan.

Hardiyanti (2012) meneliti mengenai faktor-faktoryang mempengaruhi nilai perusahaan. Berdasarkan hasil penelitian tersebut ditarik kesimpulan bahwa leverage, profitabilitas dan dividend payout ratio berpengaruh terhadap nilai perusahaan, sedangkan insider ownership dan firm size tidak berpengaruh terhadap nilai perusahaan.

\section{Perumusan Hipotesis}

Teori yang berhubungan dengan keputusan investasi adalah teori pensinyalan(signalling theory). Teori pensinyalan yang dikemukakan oleh Modigliani dan Miller (1958) menyatakan bahwa pengeluaran investasi memberikan sinyal positif terhadap pertumbuhan perusahaan di masa yang akan datang, sehingga meningkatkan harga saham sebagai indikator nilai perusahaan (Wahyudi dan Pawestri 2006).Dengan dilakukannya investasi,maka saham perusahaan akan lebih diminati oleh investor dan mengakibatkan harga saham akan meningkat. Peningkatan harga saham inilah yang dijadikan indikator bahwa nilai perusahaan juga meningkat.Pendapat di atas juga sejalan dengan pendapat Uri Ben-Zion (1984) yang mengemukakan bahwa nilai pasar perusahaan dipengaruhi oleh kegiatan penelitian dan pengembangan serta dipengaruhi kebijakan investasi.

Pendapat ini didukung oleh hasil penelitian Prapaska (2012) yang menemukan bahwa keputusan investasi berpengaruh positif terhadap nilai perusahaan.Teori diatas sejalan dengan penelitian yang dilakukan oleh Wijaya dan Wibawa (2010) yang menyatakan bahwa keputusan investasi perusahaanberpengaruh positif terhadap nilai perusahaan. Berdasarkan penjelasan di atas dirumuskan hipotesis sebagai berikut:

HA1: Keputusan investasi berpengaruh positif terhadap nilai perusahaan. 
Teori yang berhubungan dengan keputusan pendanaan yaitu pandangan pertama dikenal dengan pandangan tradisional yang menyatakan bahwa struktur modal mempengaruhi nilai perusahaan. Pandangan tradisional diwakili oleh dua teori yaitu Trade off Theory yang dikemukakan oleh Myers (2001), "Perusahaan akan berhutang sampai pada tingkat hutang tertentu, dimana penghematan pajak (tax shields) dari tambahan hutang sama dengan biaya kesulitan keuangan (financial distress)". Teori selanjutnya dari pandangan pertama yaitu Pecking Order Theory. Menurut Myers (1984),Pecking Order Theory menyatakan bahwa "Perusahaan dengan tingkat profitabilitas yang tinggi justru tingkat hutangnya rendah, dikarenakan perusahaan yang profitabilitasnya tinggi memiliki sumber dana internal yang berlimpah." (Setiawan, 2011). Pandangan kedua dikemukakan oleh Modigliani dan Miller (1958) yang menyatakan bahwa struktur modal tidak mempengaruhi nilai perusahaan.

Masulis (1980) menemukan bahwa harga saham perusahaan naik apabila diumumkan akan diterbitkan pinjaman yang digunakan untuk membeli kembali saham perusahaan tersebut.Jika harga saham naik berarti nilai perusahaan juga meningkat. Hal ini sesuai dengan hasil penelitianSan Martin dan Duran (2012) yang menemukan bahwa leverage berpengaruh positif terhadap nilai perusahaan. Dari penelitian tersebut berarti semakin tinggi hutang atau semakin besar keputusan pendanaan yang dilakukan oleh suatu perusahaan maka semakin tinggi pula nilai suatu perusahaan.Berdasarkan penjelasan $\mathrm{di}$ atas dirumuskan hipotesis sebagai berikut:

HA2: Keputusan pendanaan berpengaruh positif terhadap nilai perusahaan.

Teori yang berkaitan dengan kebijakan dividen yaitu, pertama, dividen tidak relevan, menurut Modigliani dan Miller (1958) nilai suatu perusahaan tidak ditentukan oleh pembayaran dividen, tetapi oleh earning power dari aset perusahaan. MenurutBird in Hand Theory,biaya modal sendiri akan naik sebagai akibat penurunan pembayaran dividen. Investor merasa lebih aman untuk memperoleh pendapatan berupa pembayaran dividen yang lebih pasti daripada menunggu capital gains yang lebih berisiko. Dengan demikian dividen yang tinggi akan meningkatkan nilai perusahaan. (Sawir 2004).

Fama dan French (1998) menemukan bahwa investasi yang dihasilkan dari kebijakan dividen memiliki informasi yang positif tentang perusahaan di masa yang akan datang, selanjutnya berdampak positif terhadap nilai perusahaan. Berdasarkan penjelasan di atas dirumuskan hipotesis sebagai berikut:

HA3: Kebijakan dividen berpengaruh positif terhadap nilai perusahaan.

Perusahaan besar lebih dapat mengakses pasar modal dalam memperoleh pendanaan. Dengan adanya kemudahan tersebut berarti perusahaan memiliki fleksibilitas dan kemampuan untuk mendapatkan dana (Wahidahwati 2002).Selain itu, ukuran perusahaan turut menentukan tingkat kepercayaan investor. Semakin besar ukuran perusahaan, maka semakin dikenal oleh masyarakat yang artinya semakin mudah untuk mendapatkan informasi yang akan meningkatkan nilai perusahaan. Bahkan perusahaan besar yang memiliki total aktiva yang cukup besar dapat menarik investor untuk menanamkan modalnya pada perusahaan tersebut (Prasetyorini, 2013).Itturiaga dan Sanz (1998) menyatakan bahwa semakin besar ukuran perusahaan akan semakin tinggi nilai perusahaan tersebut. Berdasarkan penjelasan di atas dirumuskan hipotesis sebagai berikut:

HA4: Ukuran perusahaan berpengaruh positif terhadap nilai perusahaan.

\section{Model Penelitian}

Penelitian ini bermaksud untuk mengetahui pengaruhkeputusan investasi, keputusan pendanaan, kebijakan dividen dan ukuran perusahaan terhadap nilai perusahaan. Dalam penelitian inikeputusan investasi, keputusan pendanaan, kebijakan dividen dan ukuran perusahaan sebagai variabel independen. Sedangkan nilai perusahaan sebagai variabel dependen. Berdasarkan hal tersebut di atas, maka model yang digunakan dalam penelitian ini adalah sebagai berikut: 


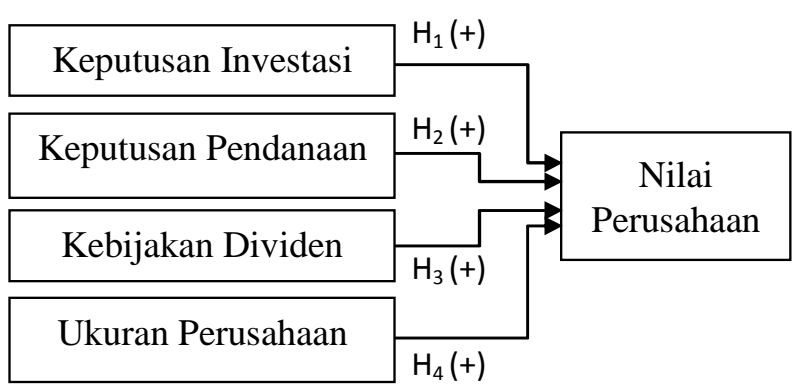

Gambar 1: Model Penelitian

\section{METODA PENELITIAN Populasi dan Sampel}

Populasi yang digunakan dalam penelitian ini adalahperusahaan manufaktur yang terdaftar di Bursa Efek Indonesia tahun 2009 - 2011. Sedangkan sampelnya diambil dengan menggunakan metoda purposive sampling. Kriteria perusahaan yang dipakai sebagai sampel dalam penelitian ini adalah perusahaan yang membagikan dividen kas dari tahun 20092011 dan tidak menunjukkan adanya saldo total ekuitas yang negatif dan atau mengalami kerugian selama tahun 2009-2011.

\section{Variabel Penelitian dan Pengukuran Variabel}

Dalam penelitian ini variabel dependen berupa nilai perusahaan. Nilai perusahaan dalam penelitian ini didefinisikan sebagai nilai pasar karena nilai perusahaan dapat memberikan kemakmuran pemegang saham secara maksimal apabila harga saham perusahaan meningkat (Hasnawati 2005). Variabel nilai perusahaan diproksikan dengan Price to Book Value (PBV).

$$
P B V=\frac{\text { Harga Saham }}{\text { Nilai buku saham }}
$$

Adapun variabel independen terdiri dari keputusan investasi, keputusan pendanaan, kebijakan dividen dan ukuran perusahaan. Keputusan investasi diukur dengan Price Earnings Ratio(PER).

$$
P E R=\frac{\text { Harga Saham }}{\text { Earning per share }}
$$

Keputusan pendanaan merupakan keputusan tentang bentuk dan komposisi pendanaan yang akan dipergunakan oleh perusahaan (Husnan dan Pudjiastuti 2006). Keputusan pendanaan diproksikan melalui Debt to Equity Ratio (DER).DER adalah total utang dibagi dengan ekuitas pemegang saham total.

$$
D E R=\frac{\text { Total hutang }}{\text { Total } \text { ekuitas }}
$$

Kebijakan dividen merupakan keputusan apakah laba akan dibayarkan sebagai dividen atau ditahan untuk reinvestasi dalam perusahaan. Dalam penelitian ini kebijakan dividen diproksikan dengan Dividend Payout Ratio (DPR).

$$
D P R=\frac{\text { Dividend per share }}{\text { Earning per share }}
$$

Ukuran perusahaan dalam penelitian ini dinyatakan dengan total aktiva, maka makin besar total aktiva perusahaan maka akan semakin besar pula ukuran perusahaan itu. Data mengenai total aktiva nilainya sangat besar jika dibandingkan dengan data pada variabel yang lain, sehingga agar setara dengan data lainnya maka ukuran perusahaan diproksikan dengan Log of Total Assets.

\section{Metoda Analisis Data}

Penelitian ini menggunakan jenis data kuantitatif berupa laporan keuangan tahunan yang dipublikasikan oleh Bursa Efek Indonesia. Dari laporan keuangan tersebut kemudian diambil data sesuai dengan variabel-variabel penelitian di atas. Dari data yang diperoleh kemudian dilakukan analisis statistik deskriptif. Selanjutnya dilakukan uji asumsi klasik yang berupa uji normalitas, multikolinearitas, autokorelasi dan heteroskedastisitas. Setelah lolos uji asumsi klasik, kemudian dilakukan uji hipotesis dengan menggunakan uji regresi berganda.

\section{HASIL DAN PEMBAHASAN Hasil Penelitian}

Penelitian dilakukan terhadap perusahaan manufaktur yang terdaftar di Bursa Efek Indonesia. Berikut ini perusahaan yang menjadi sampel penelitian. 
Setelah data diperoleh dari perusahaan yang menjadi sampel penelitian, maka data tersebut dianalisis menggunakan analisis statistik deskriptif. Hasil analisis statistik deskriptif disajikan pad tabel 2.

Dari hasil statistik deskripstif tersebut dapat diketahui bahwa jumlah observasi dalam penelitian $(\mathrm{N})$ adalah 75 . Variabel dependen yaitu nilai perusahaan (PBV) terendah adalah sebesar 0.16, nilai perusahaan tertinggi diperoleh sebesar 41.00 dan rata-rata nilai perusahaan adalah 4.0777 .

Pada variabel independen yaitu keputusan investasi (PER) terendah adalah sebesar
1.29, keputusan investasi tertinggi diperoleh sebesar 106.67 dan rata-rata keputusan investasi adalah 14.5877. Keputusan pendanaan (DER) terendah adalah sebesar 0.10, keputusan pendanaan tertinggi diperoleh sebesar 5.96 dan rata-rata keputusan pendanaan adalah 0.9996 . Kebijakan dividen (DPR) terendah adalah sebesar 0.02, kebijakan dividen tertinggi diperoleh sebesar 2.64 dan rata-rata kebijakan dividen adalah 0.4561. Ukuran perusahaan (Size) terendah adalah sebesar 11.34, ukuran perusahaan tertinggi diperoleh sebesar 14.20 dan ratarata ukuran perusahaan adalah 12.5285 .

Tabel 1:Daftar Sampel Perusahaan

\begin{tabular}{lll}
\hline No. & Index & Nama Perusahaan \\
\hline 1. & AKRA & PT AKR Corporindo Tbk \\
2. & ASFG & PT Asahimas Flat Glass Tbk \\
3. & ASGR & PT Astra Graphia Tbk \\
4. & AUTO & PT. Astra Otoparts Tbk \\
5. & BUDI & PT. Budi Acid Jaya Tbk \\
6. & CLPI & PT Colopark Indonesia Tbk \\
7. & DVLA & PT. Darya Varia Laboratoria Tbk \\
8. & DLTA & PT. Delta Djakarta Tbk \\
9. & GJTL & PT. Gajah Tunggal Tbk \\
10. & GDYR & PT. Goodyear Indonesia Tbk \\
11. & GGRM & PT. Gudang Garam Tbk \\
12. & INTP & PT. Indocement Tunggal Perkasa Tbk \\
13. & INDF & PT. Indofood Sukses Makmur Tbk \\
14. & INTA & PT. Intraco Penta Tbk \\
15. & TCID & PT. Mandom Indonesia Tbk \\
16. & MLBI & PT. Multi Bintang Indonesia Tbk \\
17. & SMGR & PT. Semen Gresik (Persero) Tbk \\
18. & IKBIPT. Sumi Indo Kabel Tbk \\
19. & SCCO & PT. Supreme Cable Manufacturing \& Commerce Tbk \\
20. & TSPC & PT. Tempo Scan Pasific Tbk \\
21. & TBLA & PT. Tunas Baru Lampung Tbk \\
22. & TURI & PT. Tunas Ridean Tbk \\
23. & UNIC & PT. Unggul Indah Cahaya Tbk \\
24. & UNVR & PT. Unilever Indonesia Tbk \\
25. & UNTR & PT. United Tractor Tbk \\
\hline
\end{tabular}

Tabel 2: Statistik Deskriptif

\begin{tabular}{lrrrrr}
\hline & $\mathrm{N}$ & Minimum & Maksimum & Rata-rata & St. Deviasi \\
\hline PBV & 75 & 0,16 & 41,00 & 4,0777 & 7,25325 \\
PER & 75 & 1,29 & 106,67 & 14,5877 & 13,93475 \\
DER & 75 & 0,10 & 5,96 & 0,9996 & 0,88571 \\
DPR & 75 & 0,02 & 2,64 & 0,4561 & 0,38551 \\
Size & 75 & 11,34 & 14,20 & 12,5285 & 0,62712 \\
\hline
\end{tabular}




\section{Uji Asumsi Klasik}

Model regresi yang digunakan dalam penelitian ini telah lolos uji asumsi klasik, yaitu:

a. Uji normalitas.

Berdasarkan hasil grafik normal probability plot, menunjukkan bahwa titik-titik menyebar di sekitar garis diagonal dan penyebarannya mengikuti arah garis diagonal. Dengan demikian dapat dinyatakan bahwa penyebaran data mendekati normal atau memenuhi asumsi normalitas.

b. Uji multikolinieritas.

Uji multikolinearitas digunakan untuk mengetahui ada tidaknya korelasi antar variabel independen dalam sebuah model regresi berganda. Untuk dapat mendeteksi ada tidaknya problem multikolinearitas pada sebuah model regresi, dapat dilakukan dengan melihat nilai Tolerance $>0,10$, dan nilai Variance Inflation Factor (VIF) harus dibawah nilai 10. Dari uji multiikolinearitas diketahui bahwa model regresi tidak terjadi korelasi diantara variabel independen.

c. Uji autokorelasi.

Uji autokorelasi bertujuan menguji apakah dalam model regresi linear ada korelasi antara kesalahan pengggangu pada periode $t$ dengan kesalahan pengganggu pada periode t-1 (sebelumnya). Pada penelitian ini menggunakan nilai Durbin-Watson (DW). Hasil perhitungan menunjukkan angka DW berada diantara 1,7383-2,2167, maka disimpulkan tidak ada autokorelasi.

d. Uji heterokesdastisitas.

Pengujian heteroskedastisitas dilakukan dengan grafik scatterplot. Hasil penelitian disimpulkan bahwa tidak ada pola yang jelas, sehingga dapat disimpulkan tidak terjadi heteroskedastisitas.

\section{Pengujian Hipotesis dan Pembahasan}

Pengujian hipotesis dilakukan dengan cara melakukan regresi atas data yang diperoleh dari penelitian.Tabel 3 adalah hasil uji regresi yang dilakukan.

Dari hasil pengujian tersebut, dapat ditentukan persamaan regresi berikut:

$$
\begin{aligned}
\mathrm{Y}= & -17,950+0,124 \mathrm{X} 1+0,697 \mathrm{X} 2+3,998 \mathrm{X} 3 \\
& +1,413 \mathrm{X} 4+\mathrm{e}
\end{aligned}
$$

\begin{tabular}{|c|c|c|c|c|c|}
\hline \multirow[b]{2}{*}{ Model } & \multicolumn{2}{|c|}{$\begin{array}{c}\text { Unstandardized } \\
\text { Coefficients }\end{array}$} & \multicolumn{2}{|c|}{$\begin{array}{l}\text { Standardized } \\
\text { Coefficients }\end{array}$} & \multirow[b]{2}{*}{ Sig. } \\
\hline & $\mathrm{B}$ & $\begin{array}{c}\text { Std. } \\
\text { Error }\end{array}$ & Beta & $\mathrm{t}$ & \\
\hline Constant & $-17,950$ & 16,680 & & $-1,076$ & 0,286 \\
\hline PER & 0,124 & 0,060 & 0,238 & 2,073 & 0,042 \\
\hline DER & 0,697 & 0,926 & 0,085 & 0,752 & 0,455 \\
\hline DPR & 3,998 & 2,146 & 0,212 & 1,863 & 0,067 \\
\hline Size & 1,413 & 1,323 & 0,122 & 1,068 & 0,289 \\
\hline
\end{tabular}

Tabel 3: Hasil Uji Hipotesis

Dari hasil pengujian hipotesis di atas, maka dapat dijelaskan sebagai berikut:

\section{Pengaruh keputusan investasi terhadap nilai perusahaan}

Dengan menggunakan tingkat signifikan sebesar $\alpha=5 \%$, diperoleh $\mathrm{P}_{\text {value }}$ sebesar 0,042 . Dikarenakan $\mathrm{P}_{\text {value }}$ lebih kecil dari 0,05, hal ini berarti pada variabel keputusan investasi berpengaruh signifikan terhadap nilai perusahaan. Hal ini menjelaskan bahwa hipotesis pertama yang menyatakan keputusan investasi berpengaruh positif terhadap nilai perusahaan terbukti. (hipotesis 1 diterima). Dengan demikian dapat disimpulkan bahwa semakin besar investasi yang dilakukan oleh suatu perusahaan, maka semakin tinggi pula nilai suatu perusahaan. Dengan dilakukannya investasi maka investor berasumsi bahwa di masa yang akan datang profitabilitas perusahaan akan meningkat. Dengan demikian investor akan lebih tertarik untuk membeli saham perusahaan yang melakukan investasi, sehingga hal ini akan mengakibatkan harga saham akan meningkat, yang pada akhirnya akan meningkatkan nilai perusahaan.

Hasil penelitian ini sejalan dengan pendapatUri Ben-Zion (1984) yang mengemukakan bahwa nilai pasar perusahaan dipengaruhi oleh aktivitas penelitian dan pengembangan serta kebijakan investasi. Hal ini menjelaskan bahwa keputusan investasi yang dilakukan perusahaan dapat meningkatkan harga pasar saham. Kenaikan atas harga saham ini pada akhirnya akan meningkatkan nilai perusahaan. Hasil penelitian ini mendukung penelitian yang dilakukan Wijaya dan Wibawa (2010) yang menemukan bahwa nilai perusahaan yang dibentuk melalui indikator nilai pasar saham sangat dipengaruhi oleh 
peluang investasi dan pengeluaran discretionary di masa yang akan datang.

\section{Pengaruh keputusan pendanaan terhadap nilai perusahaan}

Dengan menggunakan tingkat signifikan sebesar $\alpha=5 \%$, diperoleh $\mathrm{P}_{\text {value }}$ sebesar 0,455 . Dikarenakan $\mathrm{P}_{\text {value }}$ lebih besar dari 0,05 , hal ini berarti pada variabel keputusan pendanaan tidak berpengaruh signifikan terhadap nilai perusahaan. Hal ini menjelaskan bahwa hipotesis kedua yang menyatakan bahwa keputusan pendanaan berpengaruh positif terhadap nilai perusahaan tidak terbukti. (hipotesis 2 ditolak). Hasil penelitian ini mengindikasikan bahwa tinggi atau rendah hutang pada sebuah perusahaan tidak mempengaruhi nilai perusahaan. Hal ini kemungkinan karena dalam pasar modal Indonesia pergerakan harga saham dan penciptaan nilai tambah perusahaan disebabkan faktor psikologis pasar. Besar kecilnya hutang yang dimiliki perusahaan tidak terlalu diperhatikan oleh investor, karena investor lebih melihat bagaimana pihak manajemen perusahaan menggunakan dana tersebut dengan efektif dan efisien untuk mencapai nilai tambah bagi perusahaan. Dengan demikian nilai perusahaan tidak terpengaruh walaupun keputusan pendanaan berubah. Hasil penelitian ini sejalan dengan penelitian Prapaska (2012), yang menyatakan bahwa keputusan pendanaan tidak berpengaruh signifikan terhadap nilai perusahaan.

Hasil penelitian ini berbeda juga dengan hasil penelitian San Martin and Duran (2012) yang menemukan bahwa leverage berpengaruh positif terhadap nilai perusahaan. Dari penelitian tersebut berarti semakin tinggi hutang atau semakin besar keputusan pendanaan yang dilakukan oleh suatu perusahaan maka semakin tinggi pula nilai suatu perusahaan.

\section{Pengaruh kebijakan dividen terhadap nilai perusahaan}

Dengan menggunakan tingkat signifikan sebesar $\alpha=5 \%$, diperoleh $\mathrm{P}_{\text {value }}$ sebesar 0,067 . Dikarenakan $\mathrm{P}_{\text {value }}$ lebih besar dari 0,05, hal ini berarti pada variabel kebijakan dividen tidak berpengaruh terhadap nilai perusahaan. Hal ini menjelaskan bahwa hipotesis ketiga yang menyatakan bahwa kebijakan dividen berpengaruh positif terhadap nilai perusahaan tidak terbukti. (hipotesis 3 ditolak). Hasil ini mengindikasikan bahwa kemampuan perusahaan membayar dividen bukan merupakan pertimbangan utama investor dalam membeli saham. Hasil penelitian ini sejalan dengan pendapat yang dikemukakan Modigliani dan Miller (1958) bahwa nilai suatu perusahaan tidak ditentukan oleh pembayaran dividen, tetapi oleh earning power perusahaan. Jadi menurut pendapat tersebut kemampuan perusahaan dalam memperoleh laba yang dapat menarik perhatian investor. Jika banyak investor tertarik untuk membeli saham maka harga saham akan meningkat, dan pada akhirnya akan meningkatkan nilai perusahaan.

Modigliani dan Miller (1958) menyatakan bahwa, dividend payout ratio (DPR) hanya merupakan bagian kecil dari keputusan pendanaan perusahaan. Dividend Payout Ratio tidak mempengaruhi kekayaan pemegang saham. Modigliani dan Miller (1958) beragumentasi bahwa nilai perusahaan ditentukan tersendiri oleh kemampuan aktiva perusahaan untuk menghasilkan laba. Jadi kebijakan perusahaan dalam membagi laba perusahaan menjadi dividen dan laba yang ditahan tidak mempengaruhi nilai perusahaan.

\section{Pengaruh ukuran perusahaan terhadap nilai perusahaan}

Dengan menggunakan tingkat signifikan sebesar $\alpha=5 \%$, diperoleh $\mathrm{P}_{\text {value }}$ sebesar 0,289. Dikarenakan $\mathrm{P}_{\text {value }}$ lebih besar dari 0,05, hal ini berarti pada variabel ukuran perusahaan tidak berpengaruh terhadap nilai perusahaan. Hal ini menjelaskan bahwa hipotesis keempat yang menyatakan bahwa ukuran perusahaan berpengaruh positif terhadap nilai perusahaan tidak terbukti. (hipotesis 4 ditolak). Dengan demikian dapat disimpulkan bahwa ukuran perusahaan tidak berpengaruh positif terhadap nilai perusahaan, yang berarti jika ukuran perusahaan semakin besar tidak serta merta dapat meningkatkan nilai perusahaan. Hasil penelitian ini mengindikasikan bahwa para investor tidak mempertimbangkan ukuran perusahaan pada saat mereka membeli saham.

Hasil penelitian ini tidak konsisten dengan hasil penelitian Nurmayasari (2012). 
Hasil penelitian Nurmayasari (2012) menunjukkan bahwa investor mempertimbangkan ukuran perusahaan dalam membeli saham. Ukuran perusahaan dijadikan patokan bahwa perusahaan tersebut memiliki kinerja yang bagus. Ukuran perusahaan yang besar dapat menjadi indikasi bahwa perusahaan mempunyai komitmen yang tinggi untuk terus memperbaiki kinerjanya, sehingga pasar akan mau membayar lebih mahal untuk mendapatkan sahamnya karena percaya akan mendapatkan pengembalian yang menguntungkan dari perusahaan tersebut.

\section{SIMPULAN}

Penelitian ini menguji pengaruh keputusan investasi, keputusan pendanaan, kebijakan dividen dan ukuran perusahaan terhadap nilai perusahaan. Dari penelitian yang dilakukan diperoleh beberapa kesimpulan. Kesimpulan pertama yaitu keputusan investasi berpengaruh terhadap nilai perusahaan. Hal ini berati semakin besar investasi yang dilakukan oleh suatu perusahaan, maka semakin tinggi pula nilai suatu perusahaan. Dengan dilakukannya investasi maka investor berasumsi bahwa di masa yang akan datang profitabilitas perusahaan akan meningkat. Dengan demikian investor akan lebih tertarik untuk membeli saham perusahaan yang melakukan investasi, sehingga hal ini akan mengakibatkan harga saham akan meningkat, yang pada akhirnya akan meningkatkan nilai pasar perusahaan.

Kesimpulan kedua, keputusan pendanaan tidak berpengaruh terhadap nilai perusahaan. Hasil penelitian ini mengindikasikan bahwa tinggi atau rendah hutang pada suatu perusahaan tidak mempengaruhi nilai perusahaan. Hal ini kemungkinan karena dalam pasar modal Indonesia pergerakan harga saham dan penciptaan nilai tambah perusahaan disebabkan faktor psikologis pasar. Besar kecilnya hutang yang dimiliki perusahaan tidak terlalu diperhatikan oleh investor, karena investor lebih melihat bagaimana pihak manajemen perusahaan menggunakan dana tersebut dengan efektif dan efisien untuk mencapai nilai tambah bagi perusahaan. Dengan demikian nilai perusahaan tidak terpengaruh, meskipun keputusan pendanaan berubah.
Kesimpulan ketiga yakni kebijakan dividen tidak berpengaruh terhadap nilai perusahaan. Hasil ini mengindikasikan bahwa kemampuan perusahaan membayar dividen bukan merupakan pertimbangan utama investor dalam membeli saham. Hasil penelitian ini sejalan dengan pendapat yang dikemukakan Modigliani dan Miller (1958), bahwa nilai suatu perusahaan tidak ditentukan oleh pembayaran dividen, tetapi oleh earning power perusahaan. Jadi menurut pendapat tersebut kemampuan perusahaan dalam memperoleh laba yang dapat menarik perhatian investor. Jika banyak investor tertarik untuk membeli saham, maka harga saham akan meningkat, dan pada akhirnya akan meningkatkan nilai pasar perusahaan.

Kesimpulan keempat, ukuran perusahaan tidak berpengaruh terhadap nilai perusahaan. Dengan demikian dapat disimpulkan bahwa ukuran perusahaan tidak berpengaruh positif terhadap nilai perusahaan, yang berarti jika ukuran perusahaan semakin besar tidak serta merta dapat meningkatkan nilai perusahaan. Hasil penelitian ini mengindikasikan bahwa para investor tidak mempertimbangkan ukuran perusahaan pada saat mereka membeli saham.

Dalam penelitian ini sampel penelitiannya hanya perusahaan manufaktur saja. Untuk penelitian selanjutnya dapat diperluas dengan melibatkan juga perusahaan selain perusahaan manufaktur. Variabel dependen yang digunakan dalam penelitian ini hanya terkait dengan faktor internal, untuk selanjutnya dapat ditambahkan faktor eksternal, karena nilai perusahaan dipengaruhi juga oleh faktor eksternal, seperti misalnya tingkat bunga.

\section{DAFTAR REFERENSI}

Fama, E. F., dan K. R French. 1998. Taxes, financing decision and firm value. The Journal of Finance LIII (3): 819-843.

Hasnawati, S. 2005. Implikasi keputusan investasi, pendanaan, dan dividen terhadap nilai perusahaan publik di bursa efek Jakarta. Jurnal Usahawan XXXIX (9): 33-41.

Hardiyanti, N. 2012. Analisis pengaruh insider ownership, leverage, profita- 
bilitas, firm size dan dividend payout ratio terhadap nilai perusahaan. Kertas Kerja FE Universitas Diponegoro, Semarang.

Husnan, S., dan E. Pudjiastuti. 2006. Dasardasar manajemen keuangan. Yogyakarta: UPP STIM YKPN.

Itturiaga dan Sanz. 1998. Managerial ownership, accounting choices, and informativeness of earnings. Journal of Accounting and Economics 20 (1): 61-69.

Martono dan D. A. Harjito. 2010. Manajemen keuangan. Yogyakarta: Ekonisia.

Masulis, R. W. 1980. The effect of capital structure change on security prices: A study of exchange offers. Journal of Financial Economics 8 (2): 139-178.

Modigliani, F., dan M. H Miller. 1958. The cost of capital, corporation finance, and the theory of investment. American Economics Review 13 (3): 261-297.

Myers, S. C., dan N. S Majluf. 1984. Corporate financing and investment decision when firm have information that investor do not have. Journal of Financial Economics 13 (2): 187-221.

Myers, S. C. 2001. Capital structure. The Journal of Economic Perspectives 5 (2): 81-102.

Nurmayasari, A. 2012. Analisis pengaruh profitabilitas, ukuran perusahaan, leverage dan kebijakan dividen terhadap nilai perusahaan (Studi kasus pada perusahaan manufaktur di BEI tahun 2007-2010). Yogyakarta: Fakultas Ekonomi UII.

Prapaska, J. R. 2012. Analisis pengaruh tingkat profitabilitas, keputusan investasi, keputusan pendanaan dan kebijakan dividen terhadap nilai perusahaan manufaktur di BEI tahun 2009-2010. Kertas Kerja, FE Universitas Diponogoro, Semarang.

Prasetyorini, B. F. 2013. Pengaruh ukuran perusahaan, leverage, price earning ratio dan profitabilitas terhadap nilai perusahaan. Jurnal Ilmu Manajemen 1 (1): 183-196

San Martín Reyna, J. M., dan J. A. DuranEncalada. 2012. Ownership structure, firm value and investment opportunities set: Evidence from Mexican firms. Journal of Entrepreneurship, Management and Innovation (JEMI) 8 (3): $35-57$

Sawir, A. 2004. Kebijakan pendanaan dan restrukturisasi perusahaan. Jakarta: PT. Gramedia Pustaka Utama.

Setiawan, R. D. 2011. Teori struktur modal. Diakses pada 11 November 2012, dari http://setiawanzenegger10.blogspot.co m/2011/06/teori-struktur-modal.html.

Sujoko. 2007. Pengaruh struktur kepemilikan saham leverage faktor intern dan faktor ekstern terhadap nilai perusahaan (Studi empirik pada perusahaan manufaktur dan non manufaktur di bursa efek Jakarta). Jurnal Manajemen dan Kewirausahaan 9 (1): 41- 48.

Uri Ben-Zion. 1984. The R\&D and investment decision and its relationship to the firm's market value: Some preliminary results. University of Chicago Press: $299-314$.

Wahidahwati. 2002. Pengaruh kepemilikan manajerial dan kepemilikan institusional pada kebijakan hutang perusahaan: Sebuah perspektif theory agency. Jurnal Riset Akuntansi Indonesia 8 (2): 19-33.

Wahyudi, U., dan H. P Pawestri. 2006. Implikasi struktur kepemilikan terhadap nilai perusahaan dengan keputusan keuangan sebagai variabel intervening. Simposium Nasional Akuntansi 9 Padang.

Wijaya, L. R., dan B. A. Wibawa. 2010. Pengaruh keputusan investasi, keputusan pendanaan dan kebijakan dividen terhadap nilai perusahaan. Simposium Nasional Akuntansi XIII Purwokerto. 